\title{
Kualitas Sensoris dan Kimia Daging Sapi yang Beredar di Beberapa Tempat Penjualan di Kota Ambon
}

\author{
Sensory and Chemical Quality of Beef Circulating in Several Sales Points in Ambon City
}

\author{
Isye J. Liur*, Marcus Veerman, Arnolys Mahakena \\ Jurusan Peternakan, Fakultas Pertanian Universitas Pattimura \\ Jl. Ir. M. Putuhena, Kampus Poka, Ambon 97233 \\ *Penulis Korespondensi: E-mail: isye_j@yahoo.com
}

\begin{abstract}
Meat is all animal tissue and its processed products which are suitable and used as food. Meat consists of four primary tissues, namely muscle tissue, connective tissue, epithelial tissue, and nerve tissue. Beef is meat obtained from cows that are commonly used for food consumption. This study aims to determine the sensory and chemical quality of beef circulating in several sales points in Ambon City. Parametric used are sensory analysis (color, aroma, texture) and chemical analysis (water content, ash content, protein content, fat content). The research method used is using questionnaires as primary data and testing at the Chemistry Laboratory, Department of Mathematics and Natural Sciences, University of Pattimura. The data obtained will be tested using Non-Parametric Analysis namely Conformity Test. The research results show that the evaluation of panelists, it turns out that between panelists did not differ in providing an assessment because in this study, on average, panelists gave the best assessment in terms of color, aroma, and texture.
\end{abstract}

Keywords: beef, chemical quality, sensory quality

\begin{abstract}
ABSTRAK
Daging adalah semua jaringan hewan dan produk olahannya yang sesuai dan digunakan sebagai makanan. Daging terdiri dari empat jaringan utama, yaitu jaringan otot, jaringan ikat, jaringan epitel dan jaringan saraf. Daging sapi adalah daging yang diperoleh dari sapi yang biasa dan umum digunakan untuk keperluan konsumsi makanan. Penelitian ini bertujuan untuk mengetahui analisis kualitas sensoris dan kimia daging sapi yang beredar dibeberapa tempat penjualan di Kota Ambon. Parametrik yang digunakan yaitu analisis sensoris (warna, arona, tekstur) dan analisis kimia (kadar air, kadar abu, kadar protein, kadar lemak). Metode penelitian yang dipakai yaitu menggunakan kuisioner sebagai data primer dan pengujian pada Laboratorium Kimia Jurusan MIPA Universitas Pattimura. Data yang diperoleh akan diuji menggunakan analisis non parametrik yaitu uji kesesuaian. Hasil Penelitian menunjukkan Penilaian dari panelis, ternyata antar panelis tidak berbeda dalam memberikan penilaian sebab dalam penelitian ini secara rata-rata panelis memberikan penilaian yang terbaik dari segi warna, aroma dan tekstur.
\end{abstract}

Kata Kunci: daging sapi, kualitas kimia, kualitas sensoris

\section{PENDAHULUAN}

Daging dapat menimbulkan kepuasan atau kenikmatan bagi yang memakannya karena kandungan gizinya yang lengkap sehingga keseimbangan gizi untuk hidup dapat terpenuhi. Soeparno (2009) mendefinisikan daging sebagai semua jaringan hewan dan semua produk hasil pengolahan jaringan tersebut yang sesuai untuk dimakan serta tidak menimbulkan gangguan kesehatan bagi yang memakannya.

Kandungan gizi yang tinggi menjadi salah satu penyebab mudahnya daging mengalami kerusakan akibat mikroorganisme. Menurut 
Sutaryo (2004) daging sapi sangat mudah mengalami kerusakan disebabkan adanya aktivitas mikroorganisme perusak sehingga diperlukan penanganan, penyimpanan, ataupun pengolahan yang sesuai. Aktivitas mikroorganisme ini dapat mengakibatkan perubahan fisik maupun kimiawi yang tidak diinginkan sehingga daging tersebut rusak dan tidak layak untuk dikonsumsi. Oleh karena itu, perlu adanya penanganan lebih lanjut untuk mencegah adanya aktifitas mikroorganisme didalam daging, sehingga dapat menjaga dan meningkatkan kualitas dan mutu daging tersebut.

Sifat sensoris pada daging segar, merupakan aspek yang penting diperhatikan. Hal ini berkaitan dengan pertimbangan konsumen dalam memilih daging. Biasanya konsumen akan lebih mudah memilih daging melalui penampilan secara fisik yang meliputi warna, tekstur, kecerahan, kebasahan serta intensitas flavor daging segar. Menurut Soeparno (2009). Penampilan daging banyak dipengaruhi oleh faktor selama pemeliharaan, penanganan sebelum pemotongan hingga penanganan setelah pemotongan sedangkan sifat kimia daging segar terdiri dari kadar air, kadar abu, kadar protein dan kadar lemak yang ada pada daging segar.

Kebutuhan daging yang bermutu tinggi untuk memenuhi pasar tertentu seperti supermarket, hotel dan restoran berbintang maupun pasar tradisional masyarakat umum juga ekspor terus mengalami peningkatan secara signifikan.

Masih rendahnya kualitas daging yang beredar dipasaran serta adanya indikasi bahwa daging yang diperjual belikan belum sepenuhnya memenuhi standar kualitas daging dan karkas yang diharapkan konsumen menurut SNI 01-3947-1995. Mengingat sampai saat ini belum ada data informasi tentang karakteristik dan standar mutu daging yang diproses pada RPH, dan tempat penjualam yang ada di Maluku khususnya di Kota Ambon. Sehingga perlu kiranya dilakukan suatu proses analisa sehubungan dengan kualitas sensoris dan kimia daging.

Penelitian ini bertujuan untuk mengetahui analisis kualitas sensoris dan kimia daging sapi yang beredar dibeberapa tempat penjualan di Kota Ambon.

\section{METODE PENELITIAN}

Pengambilan sampel daging sapi yang diambil yaitu pada RPH (daging segar), Pasar
Mardika (daging segar), Hypermart ACC (daging dingin) dan pada Hypermart MCM (daging beku). Daging yang diambil masing-masing sebanyak $1 \mathrm{~kg}$ daging. Rancangan yang digunakan adalah rancangan acak lengkap. Daging kemudian di analisis sensoris (warna, aroma, tekstur) di laboratorium Teknologi Hasil Ternak (THT) Jurusan Peternakan Fakultas Pertanian Universitas Pattimura, dan analisis kimia (kadar air, kadar abu, kadar protein, dan kadar lemak) di laboratorium Kimia Dasar Jurusan MIPA Universitas Pattimura.

Cara pengambilan sampel daging di RPH pukul 05.00 wit, Pasar Mardika pukul 05.45 wit, Hypermart ACC pukul 10.15 wit dan pada Hypermart MCM pukul 11.00 wit kemudian pukul 12.00 wit sampel yang digunakan untuk analisis sensoris dibawa ke Laboratorium THT Jurusan Peternakan UNPATTI untuk dipotong dan di letakan wadah kemudian diberikan ke panelis. Pukul 13.00 wit, sampel yang digunakan untuk analisis kimia dibawa ke Laboratorium Kimia Jurusan MIPA UNPATTI untuk uji kadar air, abu, protein dan lemak.

Hasil untuk kualitas sensoris daging sapi yang diisi dalam kuesioner kemudian diolah secara manual dan mendapatkan data yang dicantumkan dalam tabel hasil penelitian. Panelis yang digunakan untu kualitas sensoris yaitu 20 panelis.

\section{HASIL DAN PEMBAHASAN}

\section{Kualitas Sensoris Daging Sapi}

Hasil penelitian kualitas sensoris daging sapi merupakan parameter untuk menilai baik atau tidaknya daging sapi dinilai dari segi sensoris. Kualitas sensoris daging sapi dalam penelitian ini meliputi uji warna, aroma, tekstur. Hasil penilaian dari panelis untuk kualitas sensoris daging sapi dibeberapa tempat yang berbeda dapat dilihat pada Tabel 1.

\section{Warna}

Tabel 1, menunjukkan bahwa hasil kualitas warna pada daging sapi di RPH yaitu 2,85, Pasar Mardika yaitu 2,45, Hypermart ACC yaitu 1,95 dan Hypermart MCM yaitu 1,1. Hasil pada Tabel 1 menunjukkan adanya perbedaan antara warna daging dari keempat tempat penelitian tersebut. 
Tabel 1. Rata-rata kualitas sensoris daging sapi

\begin{tabular}{llccc}
\hline \multirow{2}{*}{ No. } & \multirow{2}{*}{ Lokasi Penelitian } & \multicolumn{3}{c}{ Rata-Rata Analisis Sensoris Daging Sapi } \\
\cline { 3 - 5 } & & Warna & Aroma & Tekstur \\
\hline 1. & RPH & 2,85 & 2,70 & 3,00 \\
2. & Pasar Mardika & 2,45 & 2,50 & 2,60 \\
3. & Hypermart (Ambon City Center) & 1,95 & 1,95 & 1,70 \\
4. & Hypermart (Maluku City Mall) & 1,10 & 1,70 & 1,70 \\
\hline
\end{tabular}

Tabel 2. Hasil analisis kualitas kimia daging sapi

\begin{tabular}{clcccc}
\hline \multirow{2}{*}{ No } & \multirow{2}{*}{ Lokasi Penelitian } & \multicolumn{3}{c}{ Hasil Analisis Kimia Daging Sapi } \\
\cline { 2 - 5 } & Kadar Air & Kadar Abu & Kadar Protein & Kadar Lemak \\
\hline 1 & RPH & $75,47^{\mathrm{a}}$ & $0,70^{\mathrm{a}}$ & $22,15^{\mathrm{a}}$ & $1,33^{\mathrm{a}}$ \\
2 & Pasar Mardika & $75,30^{\mathrm{b}}$ & $0,79^{\mathrm{b}}$ & $21,34^{\mathrm{a}}$ & $1,20^{\mathrm{a}}$ \\
3 & Hypermart (Ambon City Center) & $74,69^{\mathrm{b}}$ & $0,81^{\mathrm{b}}$ & $21,04^{\mathrm{a}}$ & $3,13^{\mathrm{b}}$ \\
4 & Hypermart (Maluku City Mall) & $70,21^{\mathrm{c}}$ & $0,85^{\mathrm{b}}$ & $22,90^{\mathrm{a}}$ & $2,71^{\mathrm{c}}$ \\
\hline
\end{tabular}

Keterangan: superskrip berbeda pada kolom yang sama menunjukkan signifikan nyata $(P<0,05)$

Perbedaan warna daging bervariasi tergantung dari jenis dan usia sapi. Daging sapi yang masih muda cenderung akan berwarna pucat berbeda dengan daging sapi yang sudah dewasa. Berdasarkan data tersebut, menunjukkan daging yang berkualitas baik dari segi warna yaitu daging pada RPH sedangkan pada Hypermart MCM warna dagingnya sudah menurun.

Berdasarkan hasil pengujian sensoris, menunjukkan perbedaan yang tidak nyata pada warna daging. Menurut Lawrie (2003), warna daging sapi adalah warna merah cerah, karena dianggap daging tersebut adalah daging yang berkualitas jika dibandingkan dengan daging yang berwarna merah tua. Daging sapi yang baik harus berwarna merah segar, mengkilat, tidak pucat, seratnya halus, tidak berbau asam, tidak busuk. Sehingga dari keempat tempat pengambilan sampel daging sapi yang baik adalah RPH.

\section{Aroma}

Aroma atau bau merupakan parameter kualitas sensoris daging. Pada umumnya aroma yang diterima oleh hidung dan otak lebih banyak merupakan berbagai ramuan atau campuran empat bahan utama yaitu harum, asam, tengik, dan hangus (Winarno, 2004).

Tabel 1 menunjukkan bahwa aroma daging sapi pada RPH lebih baik dari pada Pasar Mardika, Hypermart ACC, dan Hypermart MCM. Hal ini menunjukkan adanya perbedaan antara kualitas aroma daging sapi dari keempat tempat penjualan diatas, karena daging sapi pada RPH kualiatas dagingnya segar berbeda dengan daging sapi pada
Hypermart MCM sebab pada MCM daging sapi disimpan dengan proses pembekuan daging sehingga aroma dari daging RPH lebih baik.

Aroma merupakan ciri lain yang penting dalam menilai tingkat penerimaan konsumen terhadap suatu produk pangan. Aroma daging segar tidak berbau busuk atau masam, tetapi berbau khas daging segar. Bau daging dipengaruhi oleh jenis hewan, pakan, umur daging, jenis kelamin, lama waktu dan kondisi penyimpanan (Marlina, 2012).

\section{Tekstur}

Tekstur adalah penginderaan yang dihubungkan dengan rabaan atau sentuhan. Ciri yang sering dijadikan acuan adalah kekerasan, kekohesifan dan kandungan air. Tekstur daging sapi sangat ditentukan oleh kandungan air, kandungan lemak dan jenis karbohidrat. Data pada Tabel 1, menunjukkan bahwa kualitas tekstur daging yang baik terdapat di RPH sedangkan kualitas tekstur daging yang kurang baik terdapat di Hypermart MCM sehingga terdapat perbedaan kualitas tekstur daging itu sendiri. Daging RPH lebih baik karena saat daging tersebut terasa kenyal dan apabila ditekan maka daging tersebut akan kembali ke posisi semula. Berbeda dengan daging di Hypermart MCM sebab apabila daging ditekan maka daging tersebut terasa lembek.

\section{Kualitas Kimia Daging Sapi}

Kualitas kimia daging sapi yang diamati pada penelitian ini meliputi kadar protein, kadar lemak, 
kadar air dan kadar abu pada daging sapi di beberapa tempat penjualan di Kota Ambon.

\section{Kadar Air}

Kadar air merupakan persentase kandungan air suatu bahan yang dapat dinyatakan berdasarkan berat basah atau berat kering. Hasil analisis pada empat tempat penjualan yang berbeda berkisar antara 70,21- 75,47\% sehingga dikatakan bahwa daging sapi dengan kandungan air tertinggi terdapat di tempat RPH sedangkan yang terendah terdapat pada tempat Hypermart MCM. Kemungkinan karena RPH dan Pasar Mardika menjual daging segar tanpa menjalani perlakuan pembekuan dibandingkan dengan Hypermart ACC dan Hypermart MCM, sehingga kadar Air relatif lebih banyak. Daging jika dibekukan akan dipengaruhi oleh karakter kimia dari daging itu sendiri. Dari data analisa statistik diperoleh bahwa daging di Pasar Mardika, Hypermart ACC dan Hypermart MCM tidak signifikan tetapi antara RPH terhadap Pasar Mardika, Hypermart ACC dan Hypermart MCM sangat signifikan. Sehingga kadar air pada Hypermart MCM berbeda dengan kadar air RPH karena pada Hypermart MCM daging sapi dibekukan sehingga kadar air menurun sedangkan pada RPH daging segar dan tidak ada proses pembekuan daging maka kadar air tinggi.

Proses pembekuaan yaitu proses pengawetan yang baik untuk mempertahankan mutu bahan makanan seperti daging sapi. Pembekuan merupakan proses yang memerlukan asupan energi yang tinggi, sehingga energy merupakan komponen biaya yang besar dalam proses pembekuan (Girsang, 2010). Menurut Harjanto (2006) Pada pembekuan cepat, kristal es yang lembut akan terbentuk. Jumlah air yang keluar pada saat drip dipengaruhi oleh kristal es yang terbentuk tersebut, sehingga memengaruhi jumlah cairan dalam daging. Ikatan antara protein dengan air juga mempengaruhi kadar air, Berkurangnya kemampuan daya ikat air dapat menyebabkan berkurangnya kadar air.

Daging sapi yang dipotong mengalami proses pengistirahatan, pemotongan dan proses daging menjadi karkas yang cukup baik sehingga kadar air dalam daging tidak melebihi $80 \%$ (SNI 01-28911992). Menurut Soeparno (2009) bahwa kualitas karkas yang berhubungan dengan umur dan lemak intramuskuler mempunyai pengaruh terhadap kadar air daging. Otot yang mempunyai kandungan lemak intramuskuler tinggi cenderung mempunyai kadar air yang tinggi.

\section{Kadar Abu}

Kadar abu merupakan komponen zat anorganik yang tidak terbakar dalam proses pembakaran. Hasil penelitian menujukkan rataan kadar abu daging sapi pada 4 tempat penjualan yang berbeda yaitu berkisar antara 0,70-0,85\%. Dari hasil analisis yang dilakukan maka dapat dilihat bahwa kadar abu yang tertinggi terdapat di MCM, sedangkan yang terendah terdapat di RPH. Hasil ini tidak jauh berbeda dengan kadar abu daging sapi tanpa perlakuan yang dihasilkan Suarlan (2017) berkisar $0,34-0,44 \%$. Namun, sedikit berbeda dibandingkan Abustam (2009), kadar abu daging sapi bali yakni berkisar $0,72-1,33 \%$.

Menurut Sugeng (2003), makanan yang berasal dari sumber hewani yang memiliki kadar abu yang tinggi, hal ini disebabkan karena beberapa mineral yang terkandung didalamnya seperti kalsium, besi, dan phosfat. Tinggi rendahnya kadar abu ditentukan adanya kandungan mineral sukar larut dalam daging.

Kadar abu daging sapi juga ditentukan oleh bangsa sapi, bangsa sapi bos taurus mempunyai kadar abu lebih tinggi dari bangsa sapi bos indicus. Faktor lingkungan terutama feed intake dan kandungan nutrisi bahan pakan juga menentukan kandungan nutrisi bahan pakan juga menetukan kadar abu daging sapi (Soeparno, 2009).

\section{Kadar Protein}

Protein merupakan komponen kimia terbesar dalam daging yang mempunyai peranan penting bagi pertumbuhan, perawatan sel serta sebagai sumber kalori. Kadar protein daging sapi pada tempat penjualan yang berbeda berkisar 21,04$22,90 \%$, nilai rata rata ini menunjukkan bahwa nilai kadar protein normal. Kadar protein yang dihasikan berbeda dengan kadar protein daging sapi yang dilaporkan Sari (2013) yaitu 18,82-20,50\% dan Abustam (2009) yaitu 17,90-24,01\%. Sehingga dari data analisa statistik diperoleh kadar protein daging antara RPH dan Pasar Mardika tidak signifikan begitu juga pada Hypermart ACC dan Hypermart MCM. Kadar protein lebih tinggi pada MCM sebab kadar air dari MCM rendah sebab daging sapi yang diambil dari MCM mengalami pembekuan serta daya ikat air untuk itu protein pada daging sapi dari Hypemart MCM meningkat. 
Protein daging berperan dalam pengikatan air daging, kadar protein daging yang tinggi menyebabkan meningkatnya kemampuan menahan air daging sehingga menurunkan kandungan air bebas, dan begitu pula sebaliknya (Lawrie, 2003). Kemampuan menahan air daging tinggi akan menghasilkan tekstur daging yang empuk. Pakan dan suhu merupakan salah satu faktor yang mempengaruhi kadar protein dalam daging. Menurut Fernandez et al. (2008), ternak yang diberi pakan jenis konsentrat memiliki kadar protein yang tinggi jika dibandingkan ternak yang hanya mengkonsumsi tumbuh-tumbuhan. Kenaikan suhu ruang juga mempengaruhi kadar protein dalam daging, kenaikan suhu pada potongan daging dapat menyebabkan protein myofibril dan jaringan ikat mengalami denaturasi pada tingkatan yang berbeda.

\section{Kadar Lemak}

Lemak merupakan salah satu sumber energi yang memberikan kalori paling tinggi. Kadar lemak daging sapi pada empat tempat penjualan yang berbeda berkisar $1,20-3,13 \%$. Dikemukakan oleh Abustam (2009) bahwa kandungan lemak daging sapi berkisar 1,56-4,31\%, sehingga dari data analisa statistik diperoleh ternyata antara RPH dan Pasar Mardika tidak signifikan begitu juga pada Hypermart ACC dan Hypermart MCM tidak signifikan tetapi antara RPH dan pasar Mardika terhadap Hypermart ACC dan Hypermart MCM sangat signifikan.

Menurut Buckle et al. (1987) komposisi kimia daging sapi bali untuk kadar lemak yaitu $3,0 \%$. Pada tubuh hewan ternak, lemak disimpan di bawah kulit dan di sekitar organ tertentu misalnya ginjal. Kadar lemak berkisar antara 10-50\%, tergantung jenis hewan dan dari bagian hewan mana daging tersebut berasal. Sampai batas tertentu adanya lemak daging dikehendaki karena ia membuat daging menjadi lembab selama pemasakan (Gaman dan Sherington, 1992).

Nilai rata-rata kadar lemak daging sapi berkisar pada 4,70-5,61\%, ini menggambarkan bahwa kadar lemak daging sapi masih dalam kisaran normal. Menurut Soeparno (2009), kandungan lemak otot sangat bervariasi dapat berkisar antara 1,5-13\%.

\section{KESIMPULAN}

Kualitas sensoris (warna, aroma dan tekstur) daging sapi pada RPH lebih baik dari tempat penjualan yang lain. Kualitas kimia daging sapi ternyata untuk kimia daging sapi yang beredar pada pasar Kota Ambon.

\section{DAFTAR PUSTAKA}

Abustam, 2009. Bahan Ajar Ilmu dan Teknologi Daging. Fakultas Peternakan Universitas Hasanuddin. Makassar.

Buckle, K.A., R.A. Edwards, G.H. Fleet, dan M. Wotton. 1987. Ilmu Pangan. Penerjemah: Purnomo, H. dan Adiono. Universitas Indonesia Press. Jakarta.

Dewan Standarisasi Nasional. 1992. SNI No. 012891-1992, Jakarta.

Dewan Standarisasi Nasional. 1995. SNI No. 013924-1995, Jakarta.

Fernãndez-Dueńas, D.M, A.J. Myers, S.M. Scramlin, C.W. Parks, S.N. Carr, J. Killefer, and F.K. McKeith. 2008. Carcass, meat quality and sensory characteristics of heavy body weight pigs fed. Journal Animal Science 86: 3544-3550. DOI: 10.2527/jas.2008-0899.

Gaman, P.M. dan K.B. Sherrington. 1992. Ilmu Pangan Pengantar Ilmu Pangan Nutrisi dan Mikrobiologi. Yogyakarta: UGM Press.

Girsang, A.R. 2010. Kajian Energi Pembekuaan Daging Sapi Menggunakan Mesin Pembeku Tipe Lempeng Sentuh Dengan Suhu Pembekuaan Berubah. Skripsi. Fakultas Teknologi Pertanian Institut Pertanian Bogor. Bogor.

Harjanto, D. 2006. Kualitas Kimia Daging Dada Ayam Broiler yang Pakannya Ditambahkan Campuran Minyak Ikan Kaya Asam Lemak Omega-3. Skripsi. Fakultas Peternakan Institut Pertanian Bogor.

Lawrie, R.A. 2003. Ilmu Daging. Diterjemahkan oleh Aminudin Penerbit Universitas Indonesia. Jakarta.

Marlina. 2012. Hubungan Asupan Zat Gizi dan Aktifitas Fisik Terhadap Diabetes Mellitus Tipe 2 pada Pegawai Negeri Sipil Dinas Kesehatan Provinsi Kalimantan Barat. Skripsi. Universitas Esa Unggul

Marlina, E.T., R.L. Balia, dan Y.A. Hidayati. 2012. Uji organoleptik daging ayam yang diberi ransum yang mengandung lumpur susu terfermentasi oleh Aspergillus niger. Jurnal Ilmu Ternak 12: 20-23. DOI: 10.24198/jit.v12i1.5132 
Sari. 2013. Pengaruh Lama Penyimpanan Terhadap Kualitas Fisik dan Kimia Daging Sapi yang Dimarinasi dalam Pasta Jahe. Skripsi. Fakultas Peternakan, Universitas Halu Oleo.

Sugeng, Y.B. 2003. Sapi Potong. Penebar Swadaya. Jakarta

Soeparno. 2009. Ilmu dan Teknologi Daging. Gadjah Mada University Press, Yogyakarta.

Suarlan, E. 2017. Sifat Organoleptik Fisik dan Kimia Daging Sapi Bali yang Dimarinasi
Dalam Jus Gambir (Uncaria gambir Roxb.) Pada Lama Penyimpanan Yang Berbeda. Universitas Halu Oleo, Kendari.

Sutaryo, 2004. Modul Materi Kuliah Pokok Bahasan Penyimpanan dan Pengawetan Daging. Semarang: Fakultas Peternakan Universitas Diponegoro.

Winarno, F.G. 2004. Kimia Pangan dan Gizi. PT Gramedia Pustaka Utama, Jakarta. 